\title{
TERMINATION OF PERSONAL HEALTH INSURANCE CONTRACTS BY CANCELLATION OR NONRENEWAL
}

PROPOSALS for federal health insurance legislation ${ }^{1}$ have sparked a continuing controversy throughout the past two decades. ${ }^{2}$ These proposals emanate from a growing realization of the nation's health needs, ${ }^{3}$ but have been subbornly resisted by the medical profession ${ }^{4}$ and private insurance companies. One of the major arguments of these groups has been that the economic burdens of society resulting from

${ }^{1}$ The National Health Bill of 1939, S. 1620, 76th Cong., 1st Sess. (1939); The Copper Bill, S. 3660,76 th Cong., 3d Sess. (1940); The Wagner-Murray-Dingell Bili, S. 1606,79 th Cong., 1st Sess. (1945), see 91 ConG. Rec. 10989 (1945). In 1947 four important bills were introduced into the Senate: The Administration Bill, S. 1679, 8oth Cong., Ist Sess. (1947); The Flanders-Ives Bill, S. 1970, 8oth Cong., rst Sess. (1947); The Hill Bill, S. 1456, 8oth Cong., rst Sess. (1947); and the Taft Bill, S. I $58 x$, 8oth Cong., ist Sess. (1947). See Gagliardo, American Social Insurance 460 (1949); Comment, 59 Y ALE L.J. 292 (1950).

For a text of President Eisenhower's message to Congress (January I8, 1954) suggesting the Federal Reinsurance Bill of $x 954$, H.R. Doc. No. $298,83 \mathrm{~d}$ Cong. Ist Sess. (1954), see 36 U.S. NeWS and WorLd Report 96 (Jan. 29, 1954), yoo Cong. Rec. 379-382 (1954). See also Drucker, The Medical Insurance We Need the Most, 206 HARPERS 5 I (May, I953); Willcox, The Nature, Scope and Constitutionality of the Proposed Federal Compulsory Health Insurance, 35 IowA L. REv. I69 (r949).

${ }^{2}$ See generally, Bachman, The Issue of Compulsory Health Insurance (1948); Baur, Private Enterprise or Government in Medicine (x948); Cabet, The Doctor's Bill (1935); Ewing, How Shall We Pay for Medical Care (1949); Ewing, The Nation's Health: A Ten Year Program (1938); Goldmann, Public Medical Care (1945); Goldmann, Voluntary Medical Care Insurance in the United States (1948); Josephison, Your Life Is Their Toy (1940); Kershaw, An Approach to Social Medicine (x 946); Roberts, The Cost of Health (x952); Serbein, Paying for Medical Care in the United States (1953); Simpson, Compulsory Health Insurance (1943); Sinal, Anderson, and Dollar, Health INsurance (1946); Wilson, Compulsory Health Insurance (1947). See also, Campbell and Campbell, Compulsory Health Insurance: The Economic Issues, 66 Q.J. Econ. I (Feb., I952); Falk, Medical Care Insurance-Lessons from Voluntary and Compulsory Plans, 4Y AM. J. PUB. Health 553 (May, 1951); Frothingham, The Need for National Health Insurance, 35 IowA L. REV. 164 ( (949); Goldmann, Major Areas of Achievement and Deficiency, 4I AM. Econ. Rev. 626 (May, 195I).

${ }^{3}$ For recent samplings of this increased public interest, see Hall, When Sickness Strikes a Family, 88 SURvey 26 (Jan. I952); Harris, The High Cost of Health, 128 NEW REPUBLIC I6 (Jan. 1953); Hutchison, The High Cost of Health, I74 NATION 152 (Feb. 16, 1952).

4 See Comment, The American Medical Association: Power, Purpose and Politics in Organized Medicine, 63 Y ALE L.J. 938 (1953). 
health disabilities ${ }^{5}$ can be adequately borne by voluntary health insurance. $^{6}$ Undeniably, the great expansion ${ }^{7}$ of voluntary health insurance over this same period of time has encouraged much experimentation, and with good results. By virtue of the progress thus being achieved in this field, it is probable that reasonably adequate medical-costs protection will be available to the bulk of the population in the foreseeable future. ${ }^{8}$

'The economic burden arising from sickness is two-fold: the direct burden due to the cost of cure and treatment, and the indirect burden resulting from loss of employment due to sickness. To an extent, protection against the latter exists under Workmen's Compensation Laws. As well, in four states there are statutory disability laws providing some measure of protection for unemployment due to sickness not incurred in the scope of employment. For discussion of these laws see, Gagliardo, American Social INsurance, op. cit. supra note $\mathrm{I}$, at 577 . Private insurance also extends coverage to loss of employment due to disability. Faulkner, Replacement of Income-Personal Contracts, in ACCident And Sickness Insurance i6 (McCahan ed. ig54).

'In general, voluntary health insurance in the United States is classificd into three different types according to the insuring organization: insurance companies; Blue Cross and Blue Shield; and Independent Plans, which are usually prepayment plans sponsored by local medical societies. The primary difference in the contracts of these organizations is that those of the insurance companies are for cash benefits and the latter two are for "service" benefits. See Health Insurance Council, The Health Insurance Story 30 (1953). Statistics as to the number of hospital insurance policyholders at the end of 1954 give some indication of the relative size of each. Insurance companies-56 million; Blue Cross and Blue Shield -46 million; Independent Plans-5 million. Health Insurance Council, The Extent of Voluntary Health Insurance in THE United States 4 (1955). The discussion here will be limited to insurance companies.

7 Statistics indicate a remarkable expansion. The basic coverage type is hospitalization insurance, and at the end of 1954 it was estimated that over ror million persons held hospitalization policies, as compared with 32 million in 1945 , and 76 million in 1950. The number of persons insured against surgical expenses at the end of 1954 was 86 million, as opposed to 12 million in 1945 . Insurance against medical expenses is now held by 47 million persons as opposed to 4 million in 1945. HEALTH INSURANCE Counci $\bar{L}, i d$. at 7 . In mumber of policyholders, accident and health insurance exceeds life insurance, which has 93 million insured [Id. at $\mathrm{r}_{3}$ ], though the latter is still the largest line in terms of premiums paid. Hanna, Accident and Health Insturance Development: Competition v. Law, [1955] INs. L.J. 3r8. In terms of benefits, voluntary insurance paid over 2.7 billion dollars in claims in 1954. HeAlTh INSURANCE CoUNCIL, op. cit. supra at 12.

${ }^{8}$ The fact that 100 million Americans have some sort of health insurance does not mean that a goal has been reached. Secretary of Health, Education and Welfare Hobby's suggested aim is 130 million policyholders. But a statement of the goal in these terms places an undue emphasis on quantity and overlooks the quality of this insurance. Hanna, op. cit. supra note 7 , at 327 . What is reasonably adequate protection will always be subject to conjecture, but few would hazard to suggest that it now exists for the majority of those presently insured, in the light of estimates that less than $20 \%$ of private expenditures for medical (as opposed to hospital and surgical) care are indemni- 
However, for all the progress of voluntary health insurance, adequate protection has not been extended to certain very important problem areas, which include the poor, those who suffer prolonged illness, ${ }^{9}$ and the aged and the infirm. ${ }^{10}$ Although strenuous efforts are being made by the private companies to expand their coverage to these areas, ${ }^{11}$ only partial success is likely, since the very nature of health insurance restricts even limited protection to those among the reasonably healthy who can afford it. ${ }^{12}$

fied under insurance plans. Bowers, The Nature of Accident and Sickness Insurance, in ACCidENT AND Sickness Insurance in (McCahan ed. 1954).

- Extended illness has become a major social problem. Because of low claim limits in the average policy, only a fraction of the cost of a very serious illness is indemnified by insurance. It has been estimated that, though only one-fifth of the number of illnesses are so prolonged that they are not covered by present policies, their costs aggregate one-half of the nation's medical bill. Drucker, op. cit. supra note $x$, at 52 . The seriousness of the problem, and the unlikelihood of its solution by present methods [but see note 11 infra], prompted a presidential proposal in 1954 that Congress enact legislation to enable the government to "reinsure" private carriers who undertook to cover the risk at a standard premium rate. See note 1 supra.

${ }^{10}$ These categories overlap, yet certain bases for distinction may be observed. For an analysis along these lines, see Holman and Cooley, Voluntary Health Insurance in the United States, 35 IowA L. REv. 183 ( 1949 ).

11 Of the above three problem areas, the progress being achieved in the field of frotection against "catastrophic" illness is the most promising. Recent experiments in "major-medical" policies have proven quite marketable, as attested by their significant growth. In 1951, only about 120,000 persons held such policies, as compared with $2,350,000$ at the end of 1954 . From 1953 to 1954 alone, the increase was $83 \%$. Health Insurance Council, op. cit. supra note 6 , at 9 . This type of policy is characterized by high claim limits of either $\$ 2,000, \$ 5,000$ or $\$ 10,000$ per illness, per year, or both, and a proportionate deductible provision of $\$ 100, \$ 200$ or $\$ 500$. SMITH, Meeting Medical and Surgical Expenses, in Accident AND Sickness Insurance 8I (McCahan ed. 1954). As well, there is a co-insurance provision of $20 \%$ or $25 \%$, which enlists the financial self-interest of the insured in preventing the payment of needless benefits. Sometimes a "major-medical" policy is used in conjunction with a regular policy, with a "corridor" coverage range between two policies, in which the insured is responsible for his own protection. Hanna, $A$ New Direction in Health Insurance, 45 AM. ECon. Rev. 2 (Feb. 1955).

As nearly half of the claims paid under health insurance policies are for $\$ 50$ or under, a higher degree of economy is attained in the "major-medical" policy, not only in savings from small claim elimination, but in greatly reduced administrative expense. Hanna, op. cit. supra note 7 , at 327 .

${ }^{12}$ Any protection through voluntary insurance for the aged and those with bad medical records is sparse, and where it exists, tenuous as well. Most companies limit the age of their insureds to sixty years, Miller, Health Insurance for Our Older Citizens -Present Coverage and Future Prospects, [1954] INs. L.J. Ix3, and eliminate those not in good health by their underwriting standards. See SOMMER, Underwiriting $R e-$ insurance and Claim Adjustment-Personal Commercial Contracts, in AcCIDENT AND SICKNESS INSURANCE 129 (McCahan ed. $\times 954$ ). Those who venture accepting such 
Consequently, as to these problem areas, it must be recognized that some form of federal subsidy will be necessary. ${ }^{13}$ It is therefore in the interest of everyone concerned-the companies, those now unprotected by the voluntary system, the federal government, and the taxpayersthat the extent of this federal subsidy be minimized by expanding the voluntary insurance as far as its inherent limitations will allow. The function of state legislation in this respect is to remedy the present defects, but in such a manner as not to stunt possible beneficial expansion. Illustrative of these inherent limitations and of the difficulty of remedying defects by legislation is the current controversy concerning cancellation and renewal clauses in personal health insurance contracts. ${ }^{14}$

\section{The Problem}

In general, individual health and accident policies today are of two basic types: ${ }^{15}$ those which are written only for a stated term-almost universally one year-and which must be renewed from period to period, and those whose coverage extends for life, or until a stated age is reached by the insured. The former type is designated term insurance and the latter noncancellable insurance. ${ }^{16}$ The noncancellable type ${ }^{17}$ is consider-

risks are extremely cautious. Experience dictates that the only acceptable practice is to "write out" liability on any serious disease or infirmity previously experienced by the insured. It is argned that use of these riders (see note 56 infra for an example of a rider) is a desirable practice, because it enables those who are "substandard" risks to obtain some type of insurance, and that the insured "gets his money's worth," since the illness that is eliminated by rider may make him more susceptible to, or may prolong disability from other causes. FaULKNER, Accident AND HEALTH INSURANCE 123 (1940).

${ }^{13}$ See Comment, 59 YALE L.J. 292 (1950), and Drucker, op. cit. supra note 1, at $5 \mathrm{I}$.

${ }_{14}$ Group, as opposed to individual and family, policies are not involved in the problem of cancellation and nonrenewal. Group insurance is a contract by the insurer with a group, usually an employer-union, for the protection of members of the group, usually employees. The insurer does not cancel with the group, for reasons with which this article is not concerned; but as claims rise the insurer merely passes on the cost in the form of a higher premium. See, Milliman, Contract Provisions of Group Accident and Sickness Instirance, in Accident AND Sickness Insurance 1 I4 (McCahan ed. 1954).

${ }_{15}$ Although health insurance policies may be divided into two types on the basis of duration of contract, policies otherwise exhibit a wide variation, especially in coverage provisions. BEST Co., ACCIDENT AND HEALTr GUIDE (1952) lists fifty fundamental types of accident and health insurance policies.

${ }^{10}$ See generally, FAULKNER, op. cit. supra note 12 (1940); Accident AND SICKNESS INSURANCE (McCahan ed. I954); and RuBINOW, STANDARDS OF HEALTH INSURANCE (1916).

${ }_{17}$ Noncancellable health insurance policies originated in 1907, but were not marketed with success until the late I920's. Lilly, Modern Trends in Accident and Health In- 
ably more expensive ${ }^{18}$ because a certain percentage of premiums must be set aside each year to build up reserves against, first, the general health deterioration which usually accompanies advancing age, and, second, certain other contingencies which may affect the incidence and amount of claims. ${ }^{19}$ For example, either inflation or depression in the economy will result in a drain on this reserve. ${ }^{20}$

Term insurance, on the other hand, is the traditional form of health insurance, ${ }^{21}$ comprising the great majority of policies. ${ }^{22}$ It requires a

surance, [1927] ANNALs 145. This type of policy received a sharp setback in company popularity due to the depression. See note 20 infra. However, recently the demand for a noncancellable policy, and sounder actuarial knowledge, has tempted many companies into this field. Perkins, Underwriting Personal Non-cancellable Contracts, in Accicent AND SiCKNess Insurance 149 (McCahan ed. 1954).

${ }^{18}$ Generally, the premium cost of a noncancellable policy is between one-and-onehalf times and double that of a similar policy without the noncancellable provision. Regan, Termination of Insurance Contracts, p. 3, Memorandum to the Oklahoma Legislature, 1954. Moreover, the underwriting standards are considerably higher. For example, while a physical examination is not usually required for term insurance, in noncancellable insurance it is the rule. Id. at 3. But see SoMmER, op. cit. supra note $\mathrm{x}_{2}$, at $\mathbf{1 3}_{3}$. Therefore, between higher premiums and stricter standards, fewer people are eligible for the protection such a policy would afford.

${ }^{10}$ The most illustrative of such factors is the moral hazard. In no other type of insurance is it more within the power of the insured to control both the incidence and amount of claims. Since the insurer cannot cancel, and is disinclined to resist claims, except in clear cases of "riding" the policy, he must make provision for the effects of the hazard by higher premium rates. Faulkner, op. cit. supra note 12, at 126. Another type of factor is change in the occupation or residence of the insured, which renders him more subject to sickness or injury than formerly. A third factor is the principle of adverse selection: those persons who fear or expect an impending serious illness tend, despite higher premium rates, to select insurance which offers the greatest amount of coverage and which is noncancellable.

${ }_{20}$ The adverse effects of an inflation upon health insurance with a fixed premium rate are easily recognized. The effects of a depression were demonstrated when claim volume increased one-third from 1929 to 1932, revealing the affinity between financial distress and moral hazard. Health policies were converted wholesale into a type of unemployment insurance. Concurrently, there was a falling off of premium income, as many policies lapsed and new business was at a standstill. The pinch of these factors forced many companies out of the field and necessitated reorganization of others. Faulkner, op. cit. supra note $\mathrm{x}_{2}$, at $\mathrm{x}_{4}$.

${ }^{21}$ The writing of policies for a term has been in vogue since the inception of accident and health insurance in the $1880^{\prime}$ s. Faulkner, id at 7 . Though the term principle is familiar in fire and life insurance, rarely is the term so short, or so frequently employed for the purpose of unilateral termination of the policy by the insurer. In actual practice, the renewal of a policy is a mere matter of form. In the light of this custom of renewal, the policyholder often misunderstands the nature of his orotection. See note 28 infra.

${ }^{22}$ It was estimated that in $19549 \times .6 \%$ of all accident and health policies were written on a term basis. Follmann, The A. \& H. Cancellation "Problem," The Spectator, July I 955, p. I. 
much smaller reserve, since premiums can be set at figures which will cover losses estimated to occur only during the current term. ${ }^{23}$ In addition, since all term policies contain renewal options, ${ }^{24}$ if any individual insured's claims rise disproportionately above the estimated average, the company, in its periodic re-evaluation of policyholders, ${ }^{25}$ can refuse to renew at the end of the current term; or, if there is a cancellation

${ }^{23}$ The question as to what losses "occur" within the term constitutes a thorny problem when, for example, a company refuses payment of a claim on the ground that the illness or injury originated prior to the date that the insurance was taken out. The usual clause excepting the insurer's liability for such losses reads: "[The Company hereby insures] against loss ... resulting from accidental bodily injuries sustained during the term of this policy or . . . resulting from sickness contracted and commencing during the term of this policy. ..." C.A.D.I.E., Form No. 673. Insurers argue that to include coverage of such losses is to give fire insurance when the building is burning. Hanna, op. cit. supra note 7 , at 326 . This analogy is manifestly unfair in a case where the iliness or injury perhaps originates prior to insurance, but is unknown to the insured, or, if known, its seriousness is unsuspected by him. Moreover, consider a literal application of the "pre-existing" illness clause in a case of heart trouble, where general debilitation originates at the date of birth.

The only justification for such a clause, except in clear cases, is that without it many people would not appreciate the need for insurance until they became sick. BErter Business Bureau, Facts about Accident and Health Insurance 10 (1954). The injustices (or as the insurance companies insist "misunderstandings") often brought about by application of the clause have been one of the heated issues of health insurance. A 1954 study found complaints concerning "pre-existing" conditions foremost in number and importance. Hanna, il at 325 . In response to this unfavorable criticism, the more reputable companies effected a compromise by which a defense under the clause would become "incontestable" by the company after the policy had been in force for three years. Reitz, Standard Provisions-Personal Contracts, in ACCident AND SickNess Insurance 98, 108 (McCahan ed. 1954): Statutes have been passed in soine states limiting these defenses to two years rather than three. Hanna, id. at 326 .

${ }^{24}$ The privilege of the companies to avail themselves of these termination measures is founded in contract and recognized by regulatory legislation. Uniform Standard Provisions Act $\$$ I 6 ( 1912 ) (adopted in all states), Accident and Sickness Insurance, Appendix A (McCahan ed. 1954); Uniform Individual Accident and Sickness Policy Provisions Law (1950) (adopted in thirty-five states), id., Appendix B. See Hanna, op. cit. suppra note 7 , at $32 \mathrm{I}$.

Section $4(a)(3)$ of the latter act does require five days notice to the insured prior to the exercise of either the cancellation or "option to renew" clause of the contract. The theory of the five-day notice requirement is that the policyholder then has an opportunity to secure insurance elsewhere. Follmann, The Cancellation "Problem" in Health and Accident Insurance, Monograph for the Bureau of Accident and Health Underwriters, May, 1955, p. 15. Though this provision is hardly a largess to the policyholder to begin with, even its small measure of protection serves little function; for, in the majority of cases, the reasons which caused termination by one company would operate to exclude him from obtaining insurance from another.

${ }^{25}$ Such a periodic re-evaluation of policyholders is sound underwriting practice. FAUL.KNER, op. cit. supra note 12, at 134-135. 
clause in the contract, ${ }^{26}$ the company can terminate the policy within the current term by giving notice and returning the unearned premiums. These cancellation and renewal clauses can be utilized for purposes other than reduction of risk, however; for they function as inexpensive reliefs against malingering and against misrepresentation by the insured as to his physical condition. ${ }^{27}$

Unfortunately, the insured public generally has not appreciated the distinction between term and noncancellable insurance, nor has it been aware of the precariousness of its position in view of these termination provisions. ${ }^{28}$ Hence, when an erstwhile insured discovers that the company has terminated his policy after having paid a claim or having otherwise received notice of declining health, his reaction is customarily one of surprise and indignation. In many cases, the result does appear manifestly unjust. For instance, in one recent situation a woman, who had kept a policy for almost fifteen years without making a single claim against the company, became ill and spent a week in the hospital. When she sent her claim to the company she received a notice of nonrenewal, in addition to a check in payment of the claim. She was then approaching age sixty, and felt that "the time had come when [she] might need

${ }^{20}$ Although the cancellation provision is statutorily available [see note 24 supra], because of competition, few companies utilize it. Letter from the office of the Texas Insurance Commissioner to the Duke Bar Journal, Nov. 2, 955 .

${ }^{27}$ It is true that fraud or a material misrepresentation on an application form is a defense to a claim. VANCE, Insurance $\$ 67$ ( $3 \mathrm{~d}$ ed. 195I). These defenses are diffcult to establish in a lawsuit, however; and, because of the unfavorable publicity which would result from a claim practice utilizing them, companies prefer the more expedient alternative of cancellation or failure to renew. Interview with the North Carolina legislative insurance counsel, Oct. 2 I, I 955.

${ }^{29}$ The education of the public as to the limitations of term insurance has been one of the more awkward problems of the insurance industry. Without education, there is bound to be unjustified reliance upon future protection. The problem is exacerbated by high pressure salesmanship. State insurance commissioners, having the power to control the language of a policy, require that a description of the termination provision appear clearly both within the policy and on its "first page." National Association of insurance Commsssioners, Recommended Administrative Procedure Relative to Renewability and Cancellation Provisions I (1952). In addition, checks on misleading advertising have been established. The insurance companies adopted self-regulatory measures after an investigation by the Federal Trade Commission in 1953 [Wall Street Journal, Feb. 24, 1954, p. I, col. 8; Hanna, op. cit. supra note 7, at 324] and the passage of a Louisiana statute requiriug all health insurance advertising to include a statement of the termination provisions. LA. REv. STAT., tit. 22, $\$_{1214} A(1)$ (1950). Both the Bureau of Accident and Health Underwriters and the Health and Accident Underwriters Conference adopted a code of advertising ethics for their respective member companies. Hanna, id. at 325 . 
this insurance."229 She had, of course, assumed that the premiums paid during healthier years were for protection in later life. ${ }^{30}$ Incidents of this sort have inspired a vigorous opposition to the so-called health insurance "racket,"31 and remedies have been sought from both the courts and the legislatures.

\section{Judicial Remedies}

On the whole, disappointed policyholders have met with little success in the courts. ${ }^{32}$ Nonrenewal and cancellation clauses are ordinarily given effect according to the plain meaning of their terms, ${ }^{33}$ despite the injustice of the result in many cases. Moreover, the courts have excluded evidence of the soliciting agent's misrepresentations, ${ }^{34}$ and have rejected the argument tnat an advance notice provision appurtenant to a cancellation clause should be extended by implication to the nonrenewal clause. ${ }^{35}$

\footnotetext{
${ }^{29}$ Letter to North Carolina Rep. H. Clifton Blue, Oct. 8, 1954.

${ }^{30}$ Protection of this sort could be extended by a policy guaranteed renewable up to age 65 [see note 66 infra], in which a higher premium is charged and a reserve set aside so that the policy will be "paid up" at that age. Cf. Drucker, op. cit. supra note I, at 55. At least one company is now marketing an experimental policy of this type. Address by R. F. Killion, $A$ Re-evaluation of Individual Accident and Health Instrance, at Annual Meeting of the Bureau of Accident and Health Underwriters, Sept. 26, 1955.

${ }^{31}$ As examples of expressions in this vein: Don't Fall for Phony Health Insurance, Coronet, June, 1951, p. 14; The Cancellation Racket, Greensboro [North Carolina] Daily News, May 6, 1955, p. 8, cols. 1-2. For a collection of the charges against insurance companies, sce Follmann, op. cit. supra note 24 .

${ }^{32}$ See, generally, Annots. 19 A.L.R. 530 (1939) and 161 A.L.R. 193 (1946).

${ }^{33}$ Mut. Benefit Health \& Acc. Ass'n. v. Lyon, 95 F.2d 528 (8th Cir. 1938); Prescott v. Mut. Benefit Health \& Acc. Ass'n., I33 Fla. 510 , I83 So. 3 I I (1938); Massachusctto Bonding \& Ins. Co. v. McConnel, 50 Ga.App. 87, 176 S.E. 9r I (r934); Hall v. Provident Life \& Acc. Ins. Co., 48 Ga.App. 359, I72 S.E. 721 (1934); Mut. Benefit Health \& Acc. Ass'n. v. Caver, 169 Miss. 554, 152 So. 897 (1934); Ray v. Mut. Benefit Health \& Acc. Ass'n., 220 S.W.2d 622 (Mo.App. 1949) ; National Bankers Life Ins. Co. v. Bunnell, 227 S.W.2d 851 (Tex.Civ.App. 1950); American National Ins. Co. v. Ball, 218 S.W. 71 (Tex.Civ.App. 1920); Redeman v. Preferred Acc. Ins. Co., 215 Wis. 321, 254 N.W. 515 (1934). Accord: Pac. Mut. Life Ins. Co. v. Watson, 223 Ala. 571,137 So. 414 (1931).

${ }^{34}$ Ray v. Mut. Benefit Health \& Acc. Ass'n., 220 S.W.2d 622 (Mo.App. 1949); Massachusetts Bonding \& Ins. Co. v. Wooley, I79 S.W.2d 329 (Tex.Civ.App. I944). It has also been held that previous acceptance by agents of overdue premiums will not affect a waiver of lapse and nonrenewal provisions so as to prevent a later exercise of the option by the insurer. Commonwealth Life \& Acc. Ins. Co. v. Nelligan, 220 S.W.2d 209 (Tex.Civ.App. 1949); National Life \& Acc. Ins. Co. v. Casillas, 63 S.W.2d 396 (Tex.Civ.App. I933).

${ }^{35}$ Jordan v. Wash. Nat'l. Ins. Co., 219 Ark. 530, 243 S.W.2d 367 (1951); American National Ins. Co. v. Ball, 2 I8 S.W. 7r (Tex.Civ.App. 1920); Peskins v. Associated Indemnity Corp., 189 Wash. 8, 63 P.2d 499 (I936).
} 
Where an ambiguity can be found, however, the insured is in a somewhat better position, since it is well settled that the contracts must be strictly construed against the insurer. ${ }^{36}$ For example, courts have had no difficulty in holding a nonrenewal clause void on the ground that it conflicted with the words "noncancellable" printed in bold type on the face of the policy. ${ }^{37}$ Similarly, it has been held that a provision in a policy providing for cumulative benefits depending on the length of time the policy has been in effect conflicts with the nonrenewal clause and renders it void. ${ }^{38}$

Furthermore, the courts of at least one state have granted relief to the insured even in the absence of any ambiguity in the contract provisions. In one recent case, ${ }^{39}$ the insurer gave notice of lapse at a time when premiums were not in default, and the evidence tended to show that such notice was given with the intent of avoiding impending claims. For this wrongful termination of the contract, the insured was allowed to recover both actual and punitive damages, even though the insurer was willing to continue the policy in effect. ${ }^{40}$ In another case in that

${ }^{30}$ Mut. Life Ins. Co. of N.Y. v. Hurni Packing Co., 263 U.S. 167,174 (1936). Mr. Justice Sutherland, speaking for the Court, said: "The rule is settled that, in case of ambiguity, that construction of the policy will be adopted which is most favorable to the insured. The language employed is that of the company and it is consistent with both reason and justice that any fair doubt as to the meaning of its own words should be resolved against it."

${ }^{87}$ De Land v. Fidelity Health \& Acc. Mut. Ins. Co., 325 Mich. 9, 37 N.W.2d 693 (1949). The court rejected the argument that the word "non-cancellable" meant noncancellable during any term for which premiums had been paid, holding that it meant noncancellable for the duration of the policy. See Schultz v. Benefit Ass'n. of Railway Employees of Chicago, 175 S.C. 182 , 178 S.E. 867 (1935).

Where the noncancellable provision specifically states that it is effective during periods for which the premiums have been paid, it does not conflict with the nonrenewal option clause. Smith v. Mut. Benefit Health \& Acc. Ins. Co., 10 F. Supp. I Io (W.D. Okla. 1933); J. H. Christie \& Sons v. Moore, 48 Ga.App. 359, I72 S.E. 721 (1934); Mut. Benefit Health \& Acc. Ass'n. v. Caver, I69 Miss. 554, I 52 So. 897 (1934); Ray v. Mut. Benefit Health \& Acc. Ins. Co., 220 S.W.2d 622 (Mo.App. 1949).

${ }^{38}$ Cohen v. Mut. Benefit Health \& Acc. Ass'n., 134 N.J.Eq. 499, 36 A.2d 288 (1944); Harwell v. Mut. Benefit Health \& Acc. Ass'n., 207 S.C. 150, 35 S.E.2d 160 (1945). The latter case quoted American Indemnity Co. v. Mexia Independent School Dist., 47 S.W.2d 682, 685 (Tex.Civ.App. 1932): "Insurance companies cannot thus couch their contracts in doubtful language and allow their salesmen to employ the construction most favorable to the insured to catch the unwary, and then, when the company is hailed into court, claim the benefit of the construction most favorable to it."

Contra: Mut. Benefit Health \& Acc. Ass'n. v. Lyon, 95 F.2d 528 (8th Cir. 1938); Prescott v. Mut. Benefit Health \& Acc. Ass'n., I33 Fla. 5 I0, 183 So. 3 II (1938).

${ }^{30}$ Davis v. Bankers Life \& Casualty Co., 88 S.E.2d 658 (S.C. I955).

${ }^{10}$ The court quoted from Shuler v. Equitable Life Assurance Soc'y. of U.S.; 184 
state, ${ }^{41}$ after an agent had received a request from the insured for a claim blank, he discontinued his weekly collection calls. The policy provided that default in premium payments for more than four weeks would result in lapse. A lapse occurred, and the insured brought an action for fraudulent cancellation. The court held that evidence of a deliberate departure by the insurer's agent from his established custom of collection was sufficient to raise a jury question on the issue of fraud, and that, on a favorable verdict, the plaintiff was entitled to punitive damages. ${ }^{42}$

The limitations on the above-enumerated judicial remedies must be recognized, however. Insurers can easily delete or rephrase provisions which conflict with the renewal clause. Also, a willingness to find fraudulent termination and allow punitive damages, while providing the insured with some present compensation, affords little protection with regard to future illnesses.

\section{Legislative Remedies}

The inability of the judiciary to contrive any adequate remedy has prompted action in the state legislatures; and, within the past year, a significant number of bills have been introduced, purporting to effect some solution to the problem. ${ }^{43}$ All are basically similar in that they restrict, to some extent, cancellation and nonrenewal by the insurer. The various proposals differ, however, as to the length of time during

S.C. 485,490 x 93 S.E. 46,48 (1937): "By the weight of authority, where an insurer wrongfully cancels, repudiates, or terminates the contract of insurance, the insured may at once pursue either of three courses: (I) He may elect to treat the policy as still in force, and let the test of the validity of the cancellation or repudiation wait until the policy is payable and is sued on; (2) he may sue in equity to set aside the cancellation, and to have the policy declared to be valid and in force; or (3) he may inaintain an action at law to recover damages for the wrongful cancellation or repudiation." 88 S.E.2d at 659-60.

${ }^{41}$ Hutcherson v. Pilgrim Health \& Life Ins. Co., 87 S.E.zd 685 (S.C. 1955).

${ }^{2}$ Citing Riley v. Life \& Casualty Ins. Co. of Tenn., 184 S.C. 383,192 S.E. 394 (1937), and Simmons v. Service Life \& Health Ins. Co., 223 S.C. 407,76 S.E.2d 288 (1953). Defendant insurer offered in its answer to reinstate the policy. It then argued, on appeal, that the offer eliminated any damage plaintiff might have suffered by reason of the cancellation. Said the court: "This position cannot be sustained. The trial court in effect held that the offer to reinstate the policy and remit the premiums due and in arrears presented a jury issue, and this issue was presented to the jury along with the other issues in the case." 87 S.E.2d at 687,688 .

${ }^{43}$ There have been ro bills requiring notice before cancellation or nonrenewal. N.C. GEN. STAT. $\S 5^{8-2} 51.2$ (Supp. I 955), is of this type. See notes 5 I and 52 infra. There have been 14 proposals requiring all policies to be noncancellable from the date of issue; and 26 proposals provide that all policies must be noncancellable after they have been in force for a certain period. [See, e.g., the Florida proposal. Note 44 infra]. Follmann, op. cit. supra note 24 , at 15 . 
which such restraint is imposed; and they may be divided, generally, into four categories.

The most comprehensive legislation would require all health insurance policies issued within the state to be noncancellable. ${ }^{44}$ Several bills of this type have been introduced; ${ }^{45}$ but, as yet, none has been adopted. Although this legislation would extend much greater protection to insureds, its benefits are outweighed by the inevitable premium increase, which would deprive a disproportionately greater number of people of any protection at all. ${ }^{46} \mathrm{~A}$ solution embodying substantially the same benefits without the concomitant disadvantages of prohibitive rate increases would obviously be more desirable.

In the second category, an Ohio statute. ${ }^{47}$ which becomes effective in 1956, will forbid cancellation of any policy within the calendar year for which it was issued. This statute is subject to two criticisms: It does not affect the nonrenewal option, ${ }^{48}$ and it forestalls termination for too short a period adequately to protect the insured. Similarly, a third type of proposal requires one year's notice of cancellation if the policy has been in effect for a year or more. ${ }^{49}$ It is at least arguable that the one year

" E.g., Fla. H.B. Ix: "No life insurance company nor any insurance company writing accident and sickness policies shall cancel a policy of insurance after five years from the date of issuance, except for nonpayment of premiums."

"See note 43 supra.

so "[The characteristics of noncancellable insurance] include the necessity for higher premiums, the establishment of policy reserves, more stringent underwriting practices, more restrictive policy contracts and benefits, added hazard to the financial resources of the company, less sales appeal, and more limited availability to the potential insuring [sic] buying public. Follmann, op. cit. supra note 24 , at 17 . Insurance commissioners agree. E.g.: "[A] $[$ though insurance policies can be made non-cancellable as to any particular group falling within any age or health classification, such an arrangement might adversely affect the interests of the average policyholder. ... [I]t might be that the necessary premium for the coverage would be so burdensome as to be prohibitive in the case of the average person." Letter from Albert F. Jordan, Superintendent of Insurance for the District of Columbia, to the Duke Bar Journal, Oct. 27, 1955 . Also: "We concede that it would be desirable for all accident and sickness policies to be written on a non-cancellable basis but the practicalities of the situation are that this just can't be done at a premium rate which the average person is willing to pay." Letter from Samuel E. Orebaugh, Deputy Commissioner of Insurance for the State of Iowa, to the Duke Bar Journal, Nov. I, 1955.

${ }^{\circ 7}$ Ohio Rev. Code ANN. tit. 39, $\$ 3923.04$ (Page 1954).

${ }^{18}$ Even though deprived of the privilege of cancellation within the term, the insurer can still refuse to renew at the end of the term. Since the renewal and cancellation rights are complementary, effective regulation of them must be mutually inclusive.

${ }^{10}$ Wis. H.B. 6I6A, a proposed amendment to WIs STAT. $\$ 204.3$ I (3) (b) (8) (1953), states: "The insurer may cancel this policy at any time by written notice to the insured, or mailed to his last address as shown by the records of the insurer stating when, not 
cancellation provision applies also to the renewal option; but, in any event, this statute likewise offers no long-term protection against termination.

\section{Recent North Carolina Legislation-"Limited Cancellable" Insurance}

A new North Carolina statute, ${ }^{50}$ representing the fourth type of legislation, provides for a graduated period of notice before nonrenewal or cancellation can become effective..$^{51}$ The period is proportionate to the length of time the policy has been in force, and may range from thirty days to two years. ${ }^{52}$ The rationale of this statute is that the length of time during which the insured has relied on the policy should govern the length of the notice period.

The insurance companies have asserted a determined opposition to this legislation. They argue, first, that the incidence of cancellation at

less than five days thereafter, such cancellation shall be effective, except that if such policy has been in force for one year or more, such cancellation shall not be effective for at least 12 months. ...."

${ }^{50}$ N.C. Sess. Laws 1955 c. 886 , creating N.C. Gen. STAT. $\$ 58-261.2$ (Supp. 1955), and repealing $\$ 58-25$ I.I, the uniform 5-day cancellation notice provision.

${ }^{51}$ The statute applies specifically to nonrenewal only, and there is no section dealing with cancellation clauses as such. Section 58-251.2(2) states: "No insurance company issuing individual or blanket family hospitalization or accident and health policies of insurance shall have the right to unilaterally restrict coverage, reduce benefits, or increase rates upon any contract of hospitalization or accident and health insurance which is subject to the provisions of this Act except as provided herein." Perhaps this language is sufficient to make the nonrenewal provisions applicable to cancellation clauses. Cf. 33 N.C.L. REv. 556, 557 (1955): "Certainly any right of cancellation on shorter notice than is required for nonrenewal is contrary to the spirit of C. 886 ; and possibly the court would hold that the chapter by implication forbids any cancellation at all once the annual premium has been paid."

${ }^{2}$ "Every individual or blanket family hospitalization policy and accident and health policy, other than noncancellable or nonrenewable policies, issued in North Carolina after January I, 1956 shall include the following provision:

"Renewability: This policy is renewable at the option of the policyholder unless sufficient notice of nonrenewal is given the policyholder in writing by the insurer.

"Sufficient notice shall be, during the first year of any policy, or during the first year following any lapse and reinstatement, a period of thirty days prior to the premium due date. After one continuous year of coverage and acceptance of premium for any portion of the second or subsequent year sufficient notice shall be a number of full months most nearly equivalent to one-fourth the number of months of continuous coverage from the first anniversary of the date of issue or reinstatement, to the date of mailing of such notice: Provided no period of required notice shall exceed two years." N.C. GEN. STAT. §58-251.2 (Supp. 1955).

It should be noted that C. 886 applies only to individual and blanket policies issted after January I, 1956; it does not apply to extant policies which are renewed after that date. 
present is so insignificant as to constitute no problem, certainly not enough to justify state regulation; ${ }^{53}$ and they rely implicitly upon statistical studies which show that only a minute percentage of total policies in force are terminated by the companies within a given year. ${ }^{54}$ Even assuming that these statistics are meaningful, they represent a substantial number of persons who have been deprived of insurance protection. ${ }^{54 a}$ In addition, three factors render them inappropriate and misleading. (I) The base is too large. A ratio of cancellations to the number of insureds who submit substantial claims would certainly be more illuminating. (2) Since the statistics represent only a one-year period, they do not reflect the cumulative effect of cancellation..$^{55}$ (3) In actual practice, companies, because of competition, prefer not to cancel, but rather to exclude liability for the objectionable disease and continue the policy. ${ }^{56}$ This rider-out is, in practical effect, a pro tanto cancellation which is not reflected in the statistics.

${ }^{63}$ See Follmann, op. cit. supra note 24, at 3. In 1954 the Louisiana Insurance Commissioner sent questionnaires to all other insurance commissioners for information as to complaints about health insurance. In the answers received, complaints about cancellation or renewal accounted for $8 \%$ of total. On the basis of this and the 1953 North Carolina survey [note 54 infra], one insurance spokesman concludes: "[T] he quantitative results clearly indicate that 'cancellation' is not a problem of any great magnitude." Follmann, $i d$. at so. However, a state commissioner, after a survey of cancellation aud nonrenewal in his state, reports: "The prevalence of cancellation is astounding." Letter from Thomas J. Gillooly, Insurance Commissioner for the State of West Virginia, to the Duke Bar Journal, Dec. 12, 1955. Cf. Hanna, op. cit. supra note 7, at 325: "Undoubtedly the termination problem has been overemphasized, but currently it is one of the most serious legislative and public relations difficulties."

- The North Carolina Insurance Commissioner conducted a survey of cancellation and nonrenewal in 1953 , sending questionnaires to the 219 iusurance companies, fraternal organizations and hospital associations licensed to sell health and accident insurance in the state. The results were tabulated and a report issued coveriug statistics for the 94 companies which sold individual term policies in North Carolina during the year 1952. "Cancellation" here covers nonrenewal, but not terminations because of attainment of maximum age, non-payment of premiums, or collection of maximum benefits.

59 companies reported one or more cancellations in 1952 . A total of 3862 cancellations was reported, which was $0.3658 \%$ of all North Carolina policyholders. 1334 cancellations were motivated by deterioration of health of the insured, and 966 others by "excessive claims" on the part of the insured. Cancellatious for all other reasons totaled 1562. Memorandum to Waldo C. Cheek, North Carolina Insurance Commissioner, Oct. 2, 1953 .

${ }^{54 a}$ A total of 120,000 in the year 1952 by the 94 companies covered by the North Carolina survey aloue. There are 700 companies in the accident and health insurance business. Hanna, op. cit. supra note 7 , at 3 I 8 .

${ }^{\sigma E}$ Since cancellation occurs continually, yearly statistics do not reflect the true probability that any given insured will be cancelled at some future date.

${ }^{00}$ In a recent case, a woman collected a claim against her insurer on an operation for 
Furthermore the insurers predict that this legislation will actually result in increased incidence of termination in borderline cases, since it will occasion practices of anticipatory cancellation of policyholders who display signs of developing into bad risks. ${ }^{57}$ Perhaps the statute will have such a tendency, but any evaluation of this possibility as an argument against it must take into account the extent to which such anticipatory cancellation would be feasible in view of the risk distribution factor essential to a competitive insurance business. ${ }^{58}$ Obviously the insurers cannot go very far in eliminating prospective bad risks without cutting into the broad base of policyholders necessary to sustain the losses resulting from unanticipated bad risks.

The companies also contend that the most substantial cause of cancellation and nonrenewal is the practices of lax or unscrupulous agents, who negligently or deliberately insure bad risks in order to profit from the commissions. ${ }^{59}$ These practices, of course, are more of a problem with companies which do not offer their agents renewal commissions. Consequently, the insurers argue, a better solution would be the requirement of renewal commissions $s^{60}$ and a stricter regulation of agents gen-

the removal of a tumor. Shortly thereafter, the company sent her a rider form to sign, for waiver of "any claim for indemnity on account of any loss or disability hereafter sustained which shall be caused or contributed to by tumor, tumorous growth or neoplasm." A letter accompanying the rider informed her that:

"This is a renewable term policy and it covers any loss within the policy provisions which begins during the period of time for which premium has been accepted. The company, however, shares with you the right of not renewing the policy at the end of that period.

"Our Membership Committee has agreed on a plan of policy renewal with a provision waiving liability for any future disability caused by the condition named in the enclosed rider. Under this plan, we have given the insured an opportunity of maintaining the policy for other types of disabilities rather than to discontinue the policy in its entirety." The policyholder allowed her policy to lapse. Letter to N.C. Rep. H. Clifton Blue, Oct. 8, 1954.

${ }^{67}$ Interview with the office of the North Carolina Insurance Commissioner, Oct. 21, 1955.

"s "This principle of distributing risk is the basis of all insurance." ACKERMAN, Insurance 4 (Rev. ed. 1938). See Willett, The Economic Theory of RisK and INSURANCE, ch. I (I95 I). In dealing with health risks, there are so many unknown factors to be accounted for that practically every insured, regardless of present health, can be classed as "borderline" with regard to future illness.

${ }^{5}$ Interview with the North Carolina legislative counsel for the Bureau of Accident and Health Underwriters, Oct. 11 , 1955. Cf. Follmann, op. cit. supra note 24, at 26 : "Over-use, or abuse, of the right to discontinue the insurance might come as a result of lax or insufficient underwriting."

${ }^{80}$ Most companies do provide some renewal commissions for their agents. Interview, note 57 supra. However, in determining the amount of renewal commissions, the coin- 
erally. ${ }^{61}$ This argument, however, discounts the fact that bad agent practices is only one of several important causes of the problem. ${ }^{62}$ In addition, the North Carolina legislation will have the collateral effect of discouraging such practices; for insurers, faced with the enforced continuation of bad risks for as long as two years, will have to exercise a higher degree of care in the selection of policyholders.

Finally, and perhaps most persuasively, the insurers argue that, although only a few carriers actually abuse the cancellation and nonrewal privileges, ${ }^{63}$ the law will adversely affect all companies, as well as the public, since premiums must necessarily be raised to cover the forced continuation of bad risks. A partial answer to this argument is that the more reputable companies, which at present have a smaller ratio of cancellations to total policies, will not require a sizeable premium increase. But even these companies will experience some increase in costs, ${ }^{64}$ for they will be deprived of the use of cancellation and nonre-

panies must consider that the agent who can rely on renewal commissions has less of a motivation for acquiring new business. See FAULKNER, op. cit. supra note 12, at 212 . For this reason, any legislative program attacking "bad agent" practices by requiring renewal commissions should avoid too great an infringement upon matters of internal company management.

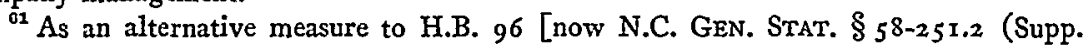
1955)], the insurers supported S.B. $35 x$, which was also enacted, and is now incorporated into N.C. GEN. STAT. $§ 58-41$ (Supp. I955). It provides that no insurance agent may be licensed in the state after May 6, 1955, unless he has been a resident for at least twelve months prior to the application for licensing, or posts a $\$ 1000$ bond with the Commissioner of Insurance. Failure to continue as a resident for one year is the only ground for forfeiture of the bond. This residence requirement is intended to remedy the abuses of transitory canvassing. Health and accident insurance agents must post an additional $\$ 500$ bond-a requirement unrelated to residence. This bond is forfeited upon a finding by the Commissioner that the agent has "willfully misrepresented the terms" of a policy. Cf. a companion section of S.B. 35 I [now N.C. GEN. STAT. § 58$54.4(9)$ (Supp. 1955)], relating to advertising of health and accident policies.

${ }^{\circ 2}$ Follmann, op. cit. supra note 24 at 6-8, lists 13 reasons, none of which specifically concerns agent practices.

${ }^{03}$ The North Carolina survey [note 54 supra] showed that eleven companies, which insured nearly one-third of all policyholders in the state, were responsible for more than two-thirds of the total cancellations. Their cancellation rate was $0.8478 \%$, as compared with $0.1616 \%$ for the remaining 83 companies. In particular, these $I x$ companies reported 993 cancellations for health deterioration, as against $34 \mathrm{I}$ for the remaining 83 companies; and 839 cancellations for excessive claims, as against 127 among the remaining companies. The $\mathrm{xI}$ companies reported 378 cancellations for moral hazard, pre-existing conditions, change of occupation, etc., as against 404 for the other 83. Memorandum to Charles F. Gold, North Carolina Insurance Commissioner, Aug. 5, 1954.

${ }^{\circ}$ Although no exact figures are presently available, one company estimates a $10 \%$ rate increase in North Carolina effective January 1, x956, and adds: "We understand that this estimate on our part is in line with that of other carriers." Letter from Herbert 
newal privileges as inexpensive reliefs against malingering and fraud. $0^{05}$

Another observation seems pertinent here. The North Carolina statute removes, to an extent, the incident of cancellation and nonrenewal from term insurance, with the result that new policies written in that state are not term policies within the traditional definition; nor are they completely noncancellable. Instead, they constitute a hybrid form which may appropriately be designated "limited-cancellable." Much of the actuarial knowledge or underwriting experience of each of the older forms is inapplicable to this new policy type, and only through trial and error can the insurers arrive at any sound underwriting basis for limitedcancellable insurance.

A final appraisal of this legislation must be made by weighing the benefits of protection to policyholders against the detriment of increased costs of insurance. Such an appraisal can be made only at some future time, when the net effects of the legislation can be more adequately determined. But, for the present, the North Carolina statute does seem commendable as the first affirmative step toward remedying the injustices of the termination problem. Even now, however, it is apparent that this legislative scheme will not give completely adequate protection, as cancellation can become effective after a relatively short period of notice. In the long run, then, a more comprehensive solution will be needed.

\section{RrCent Experiments-the Guaranteed Renewable Policy}

Probably the most auspicious effect of the recent rash of legislative proposals is the challenge they present to the health insurance companies. The incentive to minimize the problem and thus avert outside regulation has quite recently inspired a number of experimental programs and policies. The most promising of these, and the one which most closely approximates the ideal of minimum cost with maximum protection, both

B. Thompson, Vice-President of the Bankers Life and Casualty Co., to the Duke Bar Journal, Nov. 30, 1955. Another company stated only that "our premiums are going to increase considerably." Letter from W. B. Clark, Vice-President of the Carolina Casualty Insurance Co., to the Duke Bar Journal, Nov. 18, 1955 .

N.C. GEN. STAT. $\$ 58-251.2$ (1) (Supp. 1955) provides: "The insurer upon an showing of inadequacy of the rates chargeable on such policies upon which notice of nonrenewal has been given, and a finding as to the same by the Commissioner of Insurance, may increase such rates with the approval of the Commissioner."

${ }^{\circ 5}$ See note 27 supra. In addition, other legitimate grounds for cancellation are unavailable, e.g. change of occupation and moral hazard. See note ig supra. Perhaps future legislation regulating cancellation and nonrenewal should define and exclude termination for cause. See note 75 infra. 
in coverage and security of contract, is the "guaranteed renewable" policy. ${ }^{\circ 6}$ This type is not terminable by the insurer during the life of the insured, or until he reaches a specified age ${ }^{67}$ and its distinctive feature is an adjustable premium scale. Premiums may be raised to maintain reserves, but only uniformly within age brackets or other designated classifications. ${ }^{68}$ Thus, if losses become so great that premiums paid in at the current rate are insufficient to cover them, the insurer can adjust its premium scale and continue paying benefits.

This guaranteed renewable-form is preferable to the noncancellable type in that, of the two factors contributing to the high cost of the latter insurance, one is eliminated entirely-namely, the increment to premium rates necessitated by the uncertainy of general economic conditions in the future. ${ }^{69}$ The other factor, increased losses due to the general health deterioration which usually accompanies old age, cannot be eliminated. Instead the burden must rest upon the insurance companies to correlate the selection of risks with the level of premiums so as to extend the greatest possible protection to the greatest number of persons. The guaranteed renewable policy itself assures the former objective-that is, the greatest possible protection; and competition among the companies will definitely tend to accomplish the latter by adjusting premium rates at the optimum level. Also, to the extent that competition fails of that

${ }^{\text {o0 }}$ This type of policy, first offered two years ago, has received an enthusiastic response from insurance men and commissioners alike. An acknowledged authority on this problem adds a caveat, however, after discussing guaranteed renewable contracts and other recent experiments: "It is not yet possible to evaluate these experiments. Accident and health insurance is a business of delayed experience reactions. Economic swings are vital to its success or failure. Many years, and certainly a full completion of an economic cycle, are required to adequately test the result of any new decision, coverage, or experiment." Follmann, The Right of Discontinuance, Best's Insurance News, Oct. x 954, p. 77.

${ }^{07}$ Available sample policies indicate that most are guaranteed renewable only to a stated age, and that this age is usually 65 .

os Other presumably valid classifications would include sex, occupation, outstanding disabilities, etc. Follmann, op. cit. supra note 66, at 76; Hanna, op. cit. supra note 7 , at 325 .

The following is an illustrative guaranteed renewable clause: "Until the Insured reaches his $65^{\text {th }}$ birthday this policy is renewable at the option of the Insured by payment in advance, or during the grace period . . . , of premium at the Company's premium rate in force at the time of renewal for policies bearing form No. - and applicable to the [Insured at his age] on the effective date of coverage under this policy." Continental Casualty Co., form AP xо2 ז1. [Emphasis added.]

One company has recently experimented with a policy in which the premium periodically increases at stated intervals. Follmann, supra, at 76 .

${ }^{\circ 0}$ See note ig supra and accompanying text. 
purpose, supplementary legislation can spur the companies to better underwriting practices. ${ }^{70}$

\section{Conclusion}

A statute embodying a guaranteed renewable policy form would probably be an improvement upon current legislative proposals directed at the injustices of cancellation and nonrenewal. It is not recommended as an immediate step, ${ }^{71}$ however, because the actuarial knowledge essential to an intelligent determination of the standards to which insurers must conform is, at present, insufficient. Comprehensive legislation mayr be feasible in the future, when such information becomes available; whether or not it will then be necessary will depend on the extent to which the termination problem exists at that time.

In the interim, the companies, driven by competition ${ }^{72}$ and the real threat of restrictive regulation, can do much to ameliorate the problem. ${ }^{73}$ The responsibility for compelling company adherence to this objective

${ }^{70}$ N. C. GEN. STat. $\$ 58-41$ (Supp. 1955), discussed in note 61 stapra, is illustrative.

${ }^{71}$ The primary argument of the insurance companies against legislation regulating termination practices is that the premium rise will outweigh all benefits that might be achieved. See notes 46 and 64 supra. The degree to which this will be true, of course, will vary with the amount of restriction imposed; but, at any rate, it is not thought to be as great as the companies argue. Instead, perhaps such regulation would compel the companies to meet the problem by increased efficiency. In the field of individual and family health policies the companies average only $48 \%$ of the premium dollar in payment of claims (as opposed to $80 \%$ in group policies), the rest going for agents' commissions and administrative expenses. Follmann, Accident and Health Developments in 1954, Weekly Ünderwriter, Dec. 1954, p. 2. The most reputable companies pay only $60 \%$ in claims [Letter from the Educator's Mutual Insurance Co. to the Duke Bar Journal, Oct. 2I, I955], while some companies pay only $33 \%$. Interview with H. Clifton Blue, Nov. II, 1955. Even the federal government could distribute tax revenues as benefits with more economy than this. Insurance in this field serves a legitimate function, especially when there is a deductible feature based on the principle that insurance should pay only those dollars which a person, by normal budgeting, would be unable to pay [see note II supra]; but it is not thought that society will long tolerate inefficiency in a field so affected with the public interest. See EPSTEIN, INSEcuRITY, A Challenge to America 125 (Rev. ed. 1938).

${ }^{72}$ Since all companies use the same basic actuarial data, competition in the health field has not taken the form of rate cutting, but instead has been concentrated on extending better service to a greater number of policyholders. FAULKNER, op. cit. supra note I2, at 20. At present there are 700 carriers in the field [Hanna, op. cit. supra note 7 , at 318 ], and competition anong them for the remaining policyholders stiffens constantly.

${ }^{73}$ The ability and willingness of the companies to regulate themselves is demonstrated by their support of such legislation as the Uniform Fair Trade Practices Act and the Unauthorized Insurers Process Act [Hanna, op. cit. supra note 7, at 332], by their sponsorship of the three-year "incontestable" clause as to pre-existing illnesses [see note 23 supra], and by such self-regulatory measures as advertising codes [see note 28 sutpra]. 
rests with the state insurance commissioners; and it is their responsibility to recommend limited measures to the legislatures which will impel insurers to develop a solution consistent with both the public interest and the limitations of voluntary insurance. ${ }^{74}$ If the commissioners do not initiate and enforce some type of legislative leverage ${ }^{75}$ with which to secure a "voluntary" solution by the companies, state legislatures will continue to adopt comprehensive regulation as an answer to the problem. In the light of present public demand and the incubus of federal intervention, ${ }^{76}$ such a conclusion appears inescapable.

Gerald R. Gibbons

John D. Johnston, JR.

Termination practice, however, is much more fundamental in term insurance than the above matters. The extent to which the companies are capable of reappraising and revising the rate structure in their industry is, at present, conjectural. That some of them have accepted this challenge by affirmative steps is attested by the recent initiation of experimental policies. See note 68 supra.

${ }^{74} \mathrm{~A}$ committee appointed by the National Association of Insurance Commissioners, together with an All-Industry committee, is presently studying the problem of cancellation and nonrenewal. The final report from this committee is expected in mid-r 956 .

${ }^{75}$ The NAIC and All-Industry committee [note 74 supra] has the opportunity to recommend curative legislation. In this respect, we submit the following three proposals as possible recommendations:

(I) The present unlimited privilege of cancellation within a term has been subject to abuse and should be made exercisable only for cause. It is not a necessary adjunct of term insurance, and the more reputable companies have voluntarily restricted its exercise. Of course, the definition of good cause presents drafting and enforcement problems; but at least $\mathrm{jt}$ is certain that deterioration of health should be excluded. Adoption of this proposal would extend the period of insurer liability to the end of the term, and the anticipated higher claim ratjo would force the companies to adopt better underwriting standards and to reduce operating expense.

(2) Restrictions should be imposed on advertising and agent misconduct. The insurers have already shown a favorable disposition toward control of advertising practices [see note 28 supra], and the agent problem can be partially alleviated by legislation similar to N.C. GeN. STAT. \$ 5 \$-251.2 (Supp. 1955). See note 6r supra.

(3) The goal of more efficient company management can best be accomplished through closer supervision by state insurance commissioners. Closer supervision requires broader investigatory powers than are now available, especially with regard to the number of and reasons for current cancellations. Not only should the commissioners have the power to compel disclosure of such data, but they should also be given some type of concomitant sanction to compel the termination of undesirable practices.

${ }^{70}$ Federal intervention can take either of two forms: First, compulsory health insurance legislation or the Federal Reinsurance Bill. See note I supra. Second, direct federal regulation of insurance. The power here would derive from the commerce clause of the Federal Constitution as interpreted in United States $v$. South-Eastern Underwriters Assoc., 322 U.S. 533 (1944). Cf. 59 STAT. 34 (1945), 15 U.S.C. \$ Ior 2 (1952). 